\title{
HUBUNGAN MOTIVASI BELAJAR TERHADAP KEMAMPUAN PEMECAHAN MASALAH MATEMATIK SISWA SMP PADA MATERI SEGITIGA SEGIEMPAT
}

\author{
Usep Rahayu Mulyana ${ }^{1}$, Aflich Yusnita Fitrianna ${ }^{2}$ \\ 1,2 IKIP Siliwangi Cimahi \\ 11uxeprahayu@gmail.com,2kinarian2017@gmail.com
}

\begin{abstract}
The study was conducted to analyze the relationship of learning motivation to the mathematical problem solving ability of 7 th grade students. The research method is correlation. The research subjects consisted of 32 7th grade students at SMPN 3 Purwakarta. Test test instruments and non-test instruments are the methods used in data collection. The test given was in the form of 5 problem solving abilities in the form of essays and non-learning motivation scale with Likert scale. The normality test, the correlation test, the determinant coefficient, the significance test to see the correlation between the variables of learning motivation and the variables of mathematical problem solving ability are the steps taken. The conclusion from the results of the study there are $12.18 \%$ the relationship between learning motivation and problem solving abilities of junior high school students.
\end{abstract}

Keywords: Mathematical Problem Solving, Motivation to Learn

\begin{abstract}
Abstrak
Penelitian dilaksanakan untuk menganalisis hubungan motivasi belajar terhadap kemampuan pemecahan masalah matematik siswa SMP Kelas 7. Metode penelitian adalah korelasi. Subjek penelitian terdiri dari 32 siswa kelas 7 di SMPN 3 Purwakarta. Uji instrument tes dan instrument non tes merupakan metode yang dipakai dalam pengambilan data. Tes yang diberikan berupa 5 soal kemampuan pemecahan masalah berbentuk essay dan nontes skala motivasi belajar dengan skala Likert. Uji normalitas, uji korelasi, koefisien determinan, uji signifikansi untuk melihat korelasi antara variable motivasi belajar dengan variable kemampuan pemecahan masalah matematik adalah langkah-langkah yang dilakukan. Kesimpulan dari hasil penelitian terdapat 12,18\% hubungan antara motivasi belajar terhadap kemampuan pemecahan masalah siswa SMP.
\end{abstract}

Kata Kunci: Kemampuan Pemecahan Masalah Matematik, Motivasi Belajar

How to cite: Mulyana, U., R., Fitrianna, A., Y., (2019). Hubungan Motivasi Belajar Terhadap Kemampuan Pemecahan Matematik Siswa SMP Pada Materi Segitiga Segiempat. JPMI Jurnal Pembelajaran Matematika Inovatif, 2 (6), 415-420.

\section{PENDAHULUAN}

Kita sering dihadapkan dengan masalah dan tidak akan ada seorangpun yang akan terbebas dari masalah apakah sifatnya berat ataupun ringan. Masalah adalah ketidakmampuan seseorang untuk mengatasi persoalan. Permasalah yang kita hadapi setiap hari harus dicarikan solusi atau dipecahkan. Kemampuan memecahkan masalah sangat diperlukan termasuk pemikiran analistis dan keterampilan. Bagian dari kemampuan menyelesaikan masalah adalah pemikiran analistis dan keterampilan memecahkan masalah. Semakin banyak kita menyelesaikan masalah, semakin baik pula keterampilan kita dalam menyelesaikan masalah. Berdasarkan hasil penelitan Indahsari, T. I. \& Fitrianna, A. Y. (2019) mengatakan bahwa kemampuan memecahkan permasalahan siswa masih rendah dan untuk memahami konsep masih kurang. Terdapat dalam indikator mengkontruksi ulang kedalam model matematika, sehingga untuk 
meminimalisir hal tersebut, alternatif dari pilihan solusi khususnya oleh guru salah satunya dengan pemberian latihan dan belajar bermakna sehingga siswa dapat memahami inti dari konsep lebih lama.

Menurut Sugiyono (2009) masalah merupakan penyimpangan antara: yang seharusnya dengan apa yang benar-benar terjadi, teori dengan praktik, aturan dengan pelaksanaan, dan rencana dengan pelaksana. Stoner (1982) mengemukakan bahwa masalah dapat diketahui jika terdapat penyimpangan antara: pengalaman dengan kenyataan, serta apa yang direncanakan dengan kenyataan, adanya pengaduan, dan kompetisi. Menurut Hudoyo (1979) pemecahan masalah yakni suatu hal yang penting dalam pembelajaran matematika, sebab : a) Siswa akan cakap dalam menyeleksi informasi yang relevan untuk menganalisanya dan akhirnya dapat meneliti hasilnya; b) Menimbuklan kepuasan intelektual dan menjadi masalah intrinsik bagi siswa; c) Potensial intelektual siswa meningkat; d) Dengan melalui proses melakukan penemuan siswa siswa dapat belajar cara melakukan penemuan dengan baik.

Pada sekolah tempat penulis melakukan penelitian, ada beberapa pengajar ketika melakukan proses pembelajaran dilakukan tidak menggunakan RPP yang telah dibuat dan relatif lebih sering menggunakan metode konvensional pada setiap pertemuan. Menyelesaikan masalah itu memerlukan motivasi untuk melaksanakannya. Menurut Tadjab (1990) motivasi belajar adalah keseluruhan potensi penggerak di dalam diri siswa yang memunculkan kegiatan belajar, menjamin kelangsungan kegiatan belajar itu demi mencapai suatu tujuan. Sedangkan Santrock (Mardianto, 2012) mengungkapkan bahwa motivasi adalah proses yang arah, memberi semangat dan kegigihan perilaku. Menurut Vernon S. Gerlach \& Donal P. Ely (Arsyad, 2011) mengemukakan bahwa belajar merupakan perubahan perilaku, dan perilaku merupakan tindakan yang dapat diamati. Jadi perilaku merupakan kegiatan yang dapat awasi atau diamati atau bisa dikatakan sebagai hasil dari suatu tindakan yang dapat diamati.

Motivasi adalah hal yang sangat penting bagi siswa dalam. Pentingnya hal tersebut (Dimyati, 2006) adalah sebagai berikut : a) Menyadarkan kedudukan pada awal belajar, proses dan hasil akhir; b) Memberi informasi mengenai kekuatan usaha belajar, yang di bandingkan dengan teman sebaya; c) Mengarahkan kegiatan belajar; d) Membesarkan semangat belajar; e) Memberi kesadaran dengan adanya perjalan belajar setelah itu bekerja (diwaktu senggang) yang berkesinambungan. Kekuatan setiap individu adalah hal yang dilatih agar dapat. Sebagai contoh, setelah melakukan pembelajaran di sekolah siswa anjurkan untuk belajar di kediamannya masing-masing, berbakti pada orang tua dan bermain dengan temannya. Keberhasilan yang memuaskan adalah harapan dari kegiatan yang dilakukan. Berdasarkan penjabaran diatas, peneliti ingin mengetahui bagaimana hubungan antara Motivasi belajar terhadap kemampuan pemecahan masalah matematik siswa SMP. Adapun kegunaan penelitian ini dapat menjadi bahan acuan untuk melaksanakan penelitian selanjutnya

\section{METODE}

Penelitian menggunakan metode analisis, yaitu analisis korelasi. Terdapat 2 kemungkinan dalam analisis hubungan yaitu jika data yang dihasilkan berdistribusi normal maka dilakukan uji korelasi Pearson dan uji korelasi Spearman jika data yang dihasilkan tidak berdistribusi normal. Karena hasil data dihasilkan tidak berdistribusi normal maka peneliti menggunakan uji korelasi Pearson. Secara sederhana metode analisis yang digunakan dalam uji statistik yaitu teori Fancies Galton, dimana mencari hubungan antara 2 variabel yang bersifat kuantitatif yaitu. antara variable motivasi belajar dan variable kemampuan pemecahan masalah dapat diketahui dengan bantuan software SPSS 22. 
Populasi yang diambil pada penelitian siswa kelas 7 di SMP di kota Purwakarta. Sedangkan sampelnya siswa kelas 7J SMPN 3 Purwakarta yang berjumlah 32 siswa Tahun Pelajaran 2018/2019. Instrument tes dan instrument non tes merupakan metode pengambilan data yang digunakan. Instrumen tes yang pada penelitian ini yaitu berupa 5 soal kemampuan pemecahan masalah matematik dari dan instrumen non tes skala motivasi belajar siswa menggunakan skala likert.

\section{HASIL DAN PEMBAHASAN}

\section{Hasil}

Untuk mempermudah dalam menganalisis data motivasi belajar dan kemampuan pemecahan masalah maka diperlukan rekapitulasi statistik yang akan disajikan pada tabel 1 deskriptif statistika berikut:

Tebel 1. Data Deskriptif Statistik

\begin{tabular}{lrrrr}
\hline & N & Minimum & Maximum & Mean \\
\hline motivasi belajar & 32 & 29 & 94 & 73,50 \\
kemampuan pemecahan masalah & 32 & 30 & 87 & 59,75 \\
Valid N (listwise) & 32 & & & \\
\hline
\end{tabular}

\section{a. Uji normalitas}

Merupakan uji prasyarat dimana jika data berdistribusi normal dapat dilanjutkan dengan uji korelasi Product Moment Pearson dan uji korelasi Spearman jika data tidak berdistribusi normal. Kriteria pengujiannya adalah jika sig $\geq 0,05$, maka data berdistribusi normal. Jika sig $<0,05$, maka data tidak berdistribusi normal. Kolmogorov-Smirnov adalah yang dipakai dengan menggunakan aplikasi SPSS untuk mengetahui statistic uji normalitas. Uji normalitas ini dilakukan berdasarkan variabel motivasi belajar dan kemampuan pemecahan masalah matematik. Hasil uji normalitas terlampir pada tabel sebagai berikut:

Tabel.2 Uji Normalitas Data

\begin{tabular}{ccr}
\hline \multicolumn{4}{c}{ Kolmogorov-Smirnov } \\
\hline Statistik & Df & Sig. \\
\hline, 163 & 32 &, 030 \\
246 & 32 &, 000 \\
\hline \multicolumn{3}{c}{ Output } \\
\hline
\end{tabular}

Dari tabel 2 tersebut tampak bahwa nilai siginifikansi untuk motivasi belajar adalah 0,000 dan untuk kemampuan pemecahan masalah matematik sebesar 0,030. Signifikansi untuk kedua data tersebut kurang dari $0,05(\mathrm{sig}<0,05)$ yang artinya data sampel berasal dari populasi tidak berdistribusi normal.

\section{b. Uji korelasi Spearman}

Setelah data diketahui tidak berdistribusi normal, maka selanjutnya dapat dilakukan pengujian korelasi yang tujuannya untuk mengetahui nilai $r$ (korelasi) antara variabel motivasi belajar terhadap kemampuan pemecahan masalah matematik dengan menggunakan uji korelasi spearman. Dengan kriteria pengujian yaitu Jika nilai sig $<0,05$, maka berkorelasi, dan jika nilai sig $>0,05$, maka keduanya tidak berkorelasi. Berikut hasil uji korelasi menggunakan SPSS pada tabel dibawah ini: 
Tabel 3. Uji Korelasi Spearman

\begin{tabular}{lccc}
\hline \multicolumn{4}{c}{ Correlation } \\
\hline motivasi belajar & Correlation Coefficient & 1,000 &, $349^{*}$ \\
kemampuan pemecahan masalah & Correlation Coefficient &, $349^{*}$ & 1,000 \\
\hline \multicolumn{4}{c}{ Output SPSS 20 } \\
\hline
\end{tabular}

Untuk melihat tingkat hubungan korelasi dapat menggunakan tabel interpretasi (ridwan, 2010) nilai $r$ dibawah ini:

Tabel 4. Interpretasi korelasi

\begin{tabular}{|c|c|c|}
\hline \multicolumn{2}{|c|}{ Interval Koefisien } & Tingkat Hubungan \\
\hline 0,000 & - $\quad 0,199$ & Sangat rendah \\
\hline 0,200 & 0,399 & Rendah \\
\hline 0,400 & 0,599 & Cukup \\
\hline 0,600 & 0,799 & Kuat \\
\hline 0,800 & 1,00 & Sangat kuat \\
\hline
\end{tabular}

Berasarkan tabel 3 nilai r (korelasi) yang diperoleh yaitu sebesar 0,349 dan berdasarkan tabel 4 tersebut menunjukan korelasi atau hubungan motivasi belajar terhadap kemampuan pemecahan masalah matematik tergolong rendah.

\section{c. Menentukan koefisien determinan (koefisien penentu/ KP)}

Tujuan uji koefisien determinan ini yaitu untuk melihat kontribusi motivasi belajar terhadap kemampuan pemecahan masalah matematik, dengan menggunakan rumus:

$\mathrm{KP}=\mathrm{r}^{2} .100 \%$

Hasil dari uji koefisien penentu (KP) diperoleh sebesar 12,18\% sedangkan sisanya yaitu sebesar 87,82 dipengaruhi faktor lain.

\section{d. Uji signifikansi}

Untuk mengetahui signifikan atau tidaknya hubungan motivasi belajar terhadap kemampuan pemecahan masalah maka dilakukan uji signifikansi (uji t). Uji signifikansi dilakukan menggunakan SPSS, hasil uji t disajikan pada tabel dibawah ini:

\begin{tabular}{lll}
\multicolumn{3}{c}{ Tabel 5. Uji Signifikansi Data } \\
\hline \multicolumn{3}{c}{ Coefficients $^{\mathbf{a}}$} \\
\hline Model & $\mathrm{t}$ & Sig. \\
(Constan) & 2,169 & 0,038 \\
Motivasi Belajar & 1,228 & 0,229 \\
\hline \multicolumn{3}{c}{ Output SPSS 20 } \\
\hline
\end{tabular}

Berdasarkan uji t yang dilakukan didapat hasil 1,228 dengan nilai sig $>0,05$ yang artinya Ho diterima, tidak terdapat hubungan signifikan. Maka dapat ditarik kesimpulan bahwa korelasi atau hubungan motivasi belajar dengan kemampuan pemecahan masalah matematik siswa SMP adalah tidak signifikan.

\section{Pembahasan}

Dari data perhitungan pada uji korelasi dan uji signifikansi diperoleh bahwa tidak adanya hubungan signifikan antara motivasi belajar terhadap kemampuan pemecahan masalah. Berdasarkan hasil penelitian didapat bahwa data yang dihasilkan tidak berdistribusi normal yaitu $0,000<0,05$ yang artinya data sampel berasal dari populasi tidak berdistribusi normal, maka bisa dilanjutkan dengan melakukan uji korelasi Spearman. Uji korelasi dilakukan untuk memastikan kekuatan hubungan antara variabel dengan skala tertentu, sehingga dilakukan 
interpretasi tentang kekuatan hubungan antara dua variabel menggunakan tabel interpretasi, dimana menghasilkan data 0,349 dan tergolong rendah.

Setelah uji korelasi maka dilanjutkan menentukan koefisien determinasi. Koefisien determinasi (Kd) yaitu proporsi variabilitas pada model Statistik yang dapat dihitung pada suatu data. $\mathrm{Kd}$ dibuat sebagai rasio variabilitas nilai dan data asli. Kd disimbolkan $\mathrm{r}^{2}$ yang artinya hasil korelasi dikuadratkan dan secara umum untuk melihat pengaruh variabel motivasi belajar terhadap variabel kemampuan pemecahan masalah matematik. Hasil penelitian diperoleh hubungan motivasi belajar terhadap kemampuan pemecahan masalah matematik siswa SMP yaitu sebesar $12,18 \%$ sedangkan sisanya sebesar $87,82 \%$ dipengaruhi faktor lain. Dengan ini peneliti menyimpulkan bahwa motivasi belajar kurang memiliki andil terhadap kemampuan pemecahan masalah matematik. Hal ini sama dengan hasil penelitian Wulandari, A. E., Azhar, E. \& Jusra, H.(2018), tentang hubungan antara motivasi belajar terhadap kemampuan pemecahan masalah matematis siswa pada kelas 7 di SMP Jaya Suti Abadi semester genap tahun ajaran 2017/2018 yang mengatakan terdapat $10,82 \%$ besar kontribusi pengaruh motivasi belajar. Faktor lain yang mempengaruhi kemampuan pemecahan masalah matematik adalah self confidence sesuai dengan penelitian Fauziah,R., Maya, R. \& Fitrianna, A. Y. (2019) dalam hubungan motivasi belajar terhadap kemampuan pemecahan masalah matematik siswa SMP di SMP kelas 9 kota Cimahi yang mengatakan adanya hubungan yang signifikan antara self confidence terhadap kemampuan pemecahan masalah matematik siswa SMP dimana tingkat hubungannya tergolong kuat dengan pengaruh. Selain itu pengaruh Self confidence terhadap kemampuan pemecahan masalah matematik yaitu sebesar $45,16 \%$.

Terakhir untuk uji signifikansi yang tujuannya mengetahui apakah motivasi belajar berpengaruh nyata atau tidak terhadap kemampuan pemecahan masalah matematik. Dengan derajat signifikansi 0,229 dan nilai sig > 0,05 dengan aplikasi SPSS yang berarti variabel motivasi belajar mempunyai kontribusi terhadap variabel kemampuan pemecahan masalah dan menunjukan hubungan searah dan pengaruh tidak signifikan.

Berdasarkan hasil yang diperoleh maka simpulannya adalah terdapat hubungan antara motivasi belajar terhadap kemampuan pemecahan masalah siswa SMP yang tidak signifikan bahkan tergolong rendah. Selain itu, pengaruh motivasi belajar terhadap kemampuan pemecahan masalah matematik yaitu sebesar $12,18 \%$ sisanya $87.82 \%$ dipengaruhi oleh faktor lain.

\section{KESIMPULAN}

Kesimpulan dari hasil penelitian adalah terdapat hubungan antara motivasi belajar terhadap kemampuan pemecahan masalah siswa SMP yang tidak signifikan bahkan tergolong rendah. Selain itu, pengaruh motivasi belajar terhadap kemampuan pemecahan masalah matematik yaitu sebesar $12,18 \%$ sisanya $87.82 \%$ dipengaruhi oleh faktor lain

\section{DAFTAR PUSTAKA}

Arsyad, A. (2011). Media Pembelajaran. Jakarta: Rajawali Pers.

Dimyati. (2006). Belajar dan Pembelajaran. Jakarta: Rieka Cipta.

Fauziah, R., Maya, R., \& Fitriana, A. Y. (2018). Hubungan Self Confidence Terhadap Kemampuan Pemecahan Masalah Matematis Siswa SMP. Jurnal Pembelajaran Matematika Inovatif, 881886. 
Hudoyo, H. (1979). Pengembangan Kurikulum Matematika \& Pelaksanaanya di Depan Kelas. Surabaya: Usaha Nasional.

Indahsari, A. T., \& Fitrianna, A. Y. (2019). Analisis Kemampuan Pemecahan Masalah Siswa Kelas X dalam Menyelesaikan SPLDV. Jurnal Pembelajaran Matematika Inovatif, 77-86.

Mardianto. (2012). Psikologi Pendidikan. Medan: Perdana Publishing.

Mulyadi. (1991). Psikologi Pendidikan. Malang: Biro Ilmiah, FT IAIN Sunan Ampel.

Riduwan. (2010). Dasar-dasar Statistika. Bandung: Alfabeta.

Stoner, J. A. (1982). Management. New York: Prentice / Hall International.

Sugiyono. (2009). Metode Penelitian Pendidikan (Pendekatan Kuantitatif, Kualitatif, dan $R \& D$ ). Bandung: IKAPI.

Tadjab, M. (1990). Ilmu Pendidikan. Surabaya: Karya Abditama.

Wulandari, A. E., Azhar, E., \& Jusra, H. (2018). Hubungan Antara Motivasi Belajar Terhadap Kemampuan Pemecahan Masalah Matematik Siswa Kelas VII. Seminar Nasional Pendidikan Matematika, 397-405. 